\title{
Relatório sobre a participação no Convenio CAPES-FIPSE
}

\author{
Tâmara Joana Biolo Soares
}

\section{A Adaptação}

A Universidade do Texas tem seu campus principal na cidade de Austin, que é uma cidade muito acolhedora e que proporciona uma fácil adaptação à cidade. Um processo distinto é o de adaptação à Universidade do Texas. Logo no primeiro dia de aula, os professores de todas as disciplinas entregaram a ementa da disciplina e também o syllabus, no qual constavam todo o conteúdo que seria trabalhado em cada dia de aula e a respectiva leitura de artigos e/ou casos. Com o passar do tempo se começa a perceber o manancial de leitura que teríamos de enfrentar e prepatar para cada aula. Creio os maiores obstáculos à adaptação são a língua, e aqui me refiro não só ao inglês utilizado no cotidiano, mas, principalmente, ao desconhecimento do inglês jurídico, e do método de ensino.

\section{As Disciplinas}

Cursei as disciplinas Protection of Human Rights in Intemational Law, Constitutional Law, Law E Economics e Comparative Enwirommental Law, este último um short course, do qual o exame final foi após o Spring Break, ou seja, na primeira semana de abril. Isso fez sobrecarregar os dois primeiros meses, já que teríamos que ler o material de quatro meses em apenas dois, mas fez com que no período de exames, em maio, ao invés de quatro provas, tivemos três.

Os conteúdos programáticos de todas as disciplinas eram excelentes. Os estudantes têm disciplinas obrigatórias somente no primeiro ano, sendo que, nos dois anos de faculdade restantes, eles podem optar pelas mais diferentes disciplinas de acordo com suas preferencias. Isso proporciona que uma grande variedade e especialidade das matérias. Ou seja, existem matérias obrigatórias que versam sobre um tema muito especifico de determinado ramo do Direito, papel que entre nos cumpre as Disciplinas Eletivas. Foi o caso, por exemplo, de Constitutional Law II: Foreign Affairs and the Constitution, na qual não apenas estudamos o direito constitucional norte-americano, mas com o enfoque especifico naquelas decisóes e precedentes da Corte Suprema que contêm elementos de extraterritorialidade e que foram produto da ação norte-americana no cenário mundial, de suas relações externas, como as ações de soldados estrangeiros para obterem Habeas Corpus durante a Il Guerra Mundial, as discussões sobre a constitucionalidade da Guerra do Vietnã ou do bombardeio em Kosovoe, 
como encerramento do semestre, a discussão sobre se os estrangeiros detidos na base de Guantánamo, Cuba, estariam ou não sob a jurisdição dos Estados Unidos e seu direito ao Habeas Corpus. Tamanha especialidade possibilita que essas disciplinas tratem de minúcias sobre a matéria, que as discussóes sejam muito detalhadas e profundas, o que demonstra também sua dificuldade.

\section{O Método}

A metodologia utilizada nas escolas de direito, bem como na educação secundaria norte-americana, é a do método socrático. Seu conceito principal é de que não cabe ao professor ensinar ao aluno, mas questiona-lo a respeito daquilo que ele esta aprendendo para que o aluno, por si, conheça o objeto se estudo.

Assim, no syllabus de que já referi, juntamente com o conteúdo a ser ministrado em cada dia de aula, consta também a leitura que deve ser efetuada para aquele dia. Os alunos então devem preparar-se diariamente para cada aula lendo os artigos, os casos e/ou os capítulos do livro texto assinalados para a aula do dia seguinte. Em classe, o professor não irá ensinar o aluno sobre a matéria; irá sim debate-la, pois se pressupöe que os alunos já adquiriram o conhecimento retirado das leituras realizadas previamente. As aulas tornam-se, portanto, muito densas, uma vez que o professor questiona os alunos sobre suas conclusóes a respeito do que leram, se a decisão do juiz naquele caso foi correta, se o precedente foi adequadamente utilizado, se poderia ter havido outra decisăo, etc.

A participação dos alunos em classe torna-se, assim, esperada pelos professores e, para garantir que todos participarão, alguns deles passam listas para cada um assinarno dia em que deseja participar ou, menos voluntariamente, há professores que chamam os alunos pela lista de chamada.

Aqui eu me permito relatar uma curiosa experiência pessoal. En minha inscrição na Universidade do Texas, escrevi meu nome no seguinte formato: Biolo Soares, Tâmara]. Assim, em uma de minhas disciplinas em que o professor utilizava o critério da chamada para argüir os alunos, eu constava logo no inicio. Pois bem, eu fui arguida na segunda semana de aulas, quando se tem ainda pouca experiência para responder à argüição. Naquele dia, eu respondi as perguntas sobre uma decisão da Corte Européia de Direitos Humanos sobre um caso de fechamento de escolas privadas na Albânia, durante todos os 45 minutos de aula, que para mim pareceram intermináveis. No entanto, creio que o desafio foi vencidoe, foi em razão dessa experiência no inicio das aulas, que adquiri mais segurança e passei a contribuir voluntariamente nas aulas, mesmo quando não era argüida pelo professor:

Finalmente, é verdade que o método socrático utilizado na universidade americana necessita de condições muito especiais para ser posto em pratica e está também sujeito a criticas. No entanto, a experiência de conhece-lo foi entiquecedora. 


\section{A Universidade}

A par das dificuldades, muitas foram as facilidades de que desfrutamos. Dentre elas, está a excelente estrutura da biblioteca da Faculdade de Direito, com um acervo invejável desde os clássicos até as mais recentes obras em direito. Outra grande facilidade é o que se chama de Office-hours, que são horas determinadas (ao menos duas por semana) em que os professores ficam à disposição dos alunos em seus escritórios para conversas informais sobre a matéria e resolução de dúvidas.

\section{Agradecimentos}

Em verdade, seriam necessárias muitas paginas para descrever a variedade de experiências, de vivencias, de erros e acertos que a vida e o estudo em um país estrangeiro podem proporcionar. Seriam também necessárias outras tantas paginas para agradecer a todos que contribuiram para tal acontecimento.

Inicio pela Universidade do Texas por tudo que já referie também pelo estagio na Corte Interamericana de Direitos Humanos a que fui indicada depois de uma seleção pelos professores daquela Universidade. A UT mantém um convenio com a referida Corte e, na seleção de marco de 2004, indicou dois brasileiros do Convenio FIPSE-CAPES que foram posteriormente aprovados para o estagio em São José da Costa Rica, Marcio Lobato, da Federal do Pará, e eu, que tive ainda a honra de receber uma bolsa de estudos para o estagio.

Agradeço igualmente à CAPES pelo eficiente serviço que nos prestou através do atendimento aos estudantes, o pagamento das bolsas, enfim, toda a prestação dos serviços fó sempre de qualidade e seriedade e pautado pelo intuito de auxiliar os estudantes.

Agradeço à Pós-Graduação da Faculdade de Direito, a todo seu pessoal pelo auxilio incessantee, muito especialmente, à Professora Doutora Claudia Lima Marques pela orientação, pela luta incansável pela excelência acadêmica de nossa Faculdade e por proporcionar sempre mais oportunidades de crescimento acadêmico a nossos estudantes.

Finalmente, agradeço à Universidade Federal do Rio Grande do Sul, à qual tudo devo, e faço aqui especial referencia à iniciaçāo científica, da qual decorre um aprendizado de pesquisa, raciocinio, organização e disciplina que hoje reputo como essenciais à formação acadêmica. AUFRGS, meu muito obrigada. 